\title{
SOCIAL ENTREPRENEURSHIP IN BULGARIA AND EUROPE
}

\author{
Venelin Terziev \\ Academician of the Russian Academy of Natural History, Moscow, Russia, \\ Prof. D.Sc. (Ec.), D.Sc. (National Security), D.Sc. (Social Activities), Ph.D., National Military \\ University, Veliko Tarnovo, Bulgaria; University of Rousse, Rousse, Bulgaria, terziev@skmat.com
}

\begin{abstract}
In the last decade the concept of development and promotion of social economy and social entrepreneurship are part of the EU policy to tackle the social exclusion of persons in a vulnerable position. Also, the model of social economy is one of the key instruments for achieving social objectives within the framework of the sustainable and inclusive growth. Social benefits are measured by integration and employment of disadvantaged people, the contribution to the process of social inclusion of other vulnerable people, and the economic indicator is expressed by saved public funds for social welfare, on the one hand, and the additional funds compensating the social costs of long-term unemployment. What is important to happen is to create suitable conditions for the development of social enterprises with the widest possible range - vulnerable groups themselves and their problems are diverse and different, and the „answer" to their needs must be flexible in order to be efficient and effective; the "way to solutions" is not important - the paths may be different, as are diverse and vast opportunities for economic initiatives that leads to the result itself, the result is important - better integration and sustainable tackling of social exclusion.
\end{abstract}

Keywords: social entrepreneurship, social enterprise, social economy.

\section{INTRODUCTION}

A fast growing world population, swelling middle class, scarcity of natural resources and the effects of climate change are considered to be the great challenges of our time. In this rapidly evolving world, companies face serious supply chain issues and governments struggle to deal with society's most pressing problems. Very often, resolving those problems goes beyond the direct outreach of public services, charities and corporate responsibility programs. Neither charity organizations nor traditional corporates have been able to eradicate poverty, hunger, ignorance and environmental degradation. Therefore, a new approach is needed to tackle social and environmental issues and achieve sustainable economic prosperity. This approach is called social entrepreneurship. Social entrepreneurs target societal problems and provide innovative solutions by using market mechanisms. More specifically, a social enterprise has a societal mission: „impact first”. At the same time, its mission is achieved in a financially viable manner.

Europe is facing enormous challenges:

- Economic crisis - unemployment and poverty and social exclusion levels have reached record highs. They are a huge drain on Europe's human resources at a time when public budgets are under pressure. 
- Demographic changes - the working-age population in Europe is shrinking, while the proportion of older people is growing. Solutions must be found to ensure sustainable and adequate social protection systems.

Thus, Europe is facing challenges which require solutions that combine economic and social well-being. Promoting social entrepreneurship and social enterprise, especially during the current harsh economic climate, will harness both its growth potential and its added social value. In order to realise its potential, a comprehensive political framework should be developed and implemented involving a broad range of stakeholders from all sectors of society (civil society, private, public) at all levels, (local, regional, national and European).

In the past decade, interest in social enterprise has grown steadily. Governments and public bodies are looking to social enterprises to deliver sustainable services and get local economies moving. This calls for successful partnerships between local authorities and social enterprises. Social enterprises have been delivering public services for years. The social enterprise approach is increasingly seen as a way in which commissioners can find innovative solutions to unmet needs, and 'create' or 'stimulate' the market to address these. Social enterprises build social as well as financial capital; they provide essential, costeffective services for the public sector. Distributing profits to shareholders is never the priority for social enterprises - the majority of profits are reinvested and so resources remain rooted in communities, creating multiplier effects when spent.

In many countries the role of the government in the socio-economic domain is shifting towards privatization of public responsibilities. As a result, charities receive less public funds and social entrepreneurship is gaining momentum worldwide. Research in the fields of activity of social enterprises in Europe shows that social entrepreneurs focus on social services, employment \& training, the environment (including cleantech and bio-systems), education and community development. Hence, the increasing number of social enterprises may result in widespread gains for public budgets.

Social enterprises are businesses that trade for a specific social, environmental or cultural purpose. Like all businesses, social enterprises operate in commercial markets, generating a profit from their trade. However, unlike other businesses, social enterprises exist to fulfil their overriding and specific social purpose and this is at the heart of every social enterprise, driving everything it does. Around the world social enterprises have lots of different kinds of social, environmental and cultural purposes, reflecting the diverse needs and interests of the communities they work in.

Whilst there are common themes and issues, the examples are quite different - but they all serve to highlight the diversity of the social enterprise sector and demonstrate the very significant contributions these organisations make to the "world around us". Sustainable communities worldwide and a sustainable environment are critical issues. They can be served in many ways. Enterprises which themselves are selfsustaining play a crucial role. In every case they need an entrepreneur at their heart and they need to build a synergistic network of interested parties or stakeholders. They also need to deliver - and be recognized for delivering - value.

The need for social entrepreneurship develops new models of active social support and involvement in which users and customers are encouraged to assume greater responsibility. The social benefits are measured by the integration and the employment of disadvantaged people, the contribution to the process of social inclusion and the creation of social capital. The most serious economic indicator of the benefits of social economy are saved public funds for social welfare, on one hand, and additional funds to compensate the social cost of long-term unemployment, on the other.

Social enterprises contribute to society in many ways. Among other things, they:

- Tackle social and environmental problems;

- Raise the bar for corporate responsibility;

- Improve public services and shape public service design particularly as ethical consumerism increases in popularity;

- Offer a high level of engagement with users and a capacity to build their trust;

- Pioneer new approaches;

- Attract new people to business;

- Encourage under-represented groups (e.g. women, youth and offenders);

- Generate new employment opportunities. 
Social enterprises challenge and help the public sector to improve the way they design and deliver services. They bring innovative ideas and a 'can-do' attitude and can work in some of the communities that are hardest to reach. At the same time they raise standards for ethical business and corporate social responsibility.

It is recognized that social enterprises contribute to its vision of a fairer, more just society - and, so, to a number of its key targets. Contributions come through:

- Meeting social needs, using business success to address social or environmental challenges such as regeneration and social inclusion;

- Encouraging ethical markets, raising the bar for corporate responsibility;

- Improving public services, by shaping service design, pioneering new approaches and delivering services;

- Improving levels of enterprise, showing that ethical commitment and business success can be combined.

Successful social enterprises can play an important role in helping deliver on many of the Government's key policy objectives by:

- Helping to drive up productivity and competitiveness;

- Contributing to socially inclusive wealth creation; enabling individuals and communities to work towards regenerating their local neighbourhoods;

- Showing new ways to deliver and reform public services;

- And helping to develop an inclusive society and active citizenship.

Social enterprise is not a silver bullet, but it is a promising approach to fulfilling unmet needs and fostering genuinely "triple-bottom-line" organizations. It's certainly not the only solution, but it is most definitely a solution (Georgiev, 2016; Georgiev, 2017-a; Terziev, Kanev, 2019; Terziev, 2019a-k).

\section{SOCIAL ENTERPRISES IN EUROPE}

In the countries of the European Union the approach to the regulation of the social enterprises is different and follows the logic of development of the socio-economic relations, as well as the traditions in their legislative practice. In most countries there are still no specific laws to regulate the status of a separate legal entity, and namely the social enterprise. In most cases, the practice shows that the social enterprises take the form of cooperatives and that is especially popular in the countries of Southern Europe (Italy, Spain, Portugal, Greece). At the other extreme are social enterprises registered as commercial entities with social objectives (Lithuania, Finland, England) and also cooperative associations in public interest (France). In all countries, in one form or another, non-profit organizations participate actively as social enterprises in practice or there is no legal prohibition to function as such. Despite the existing differences in the legal framework for the social enterprises, there are general principles which allow the social enterprise to be defined as a non-state entity pursuing economic activities for the realization of social goals (Terziev, 2019ak).

Social enterprises employ some 14.5 million people, $6.5 \%$ of the workforce. They are active in all parts of the economy, from farming and housing to manufacturing, banking and advanced services. They make a major contribution to providing social services for vulnerable people and to providing jobs for long-term unemployed, disabled and excluded people, thus aiding their inclusion in society. They play a major role in the development of communities and local economies.

The social and economic phenomenon 'social economy' is widespread and in evident expansion across the EU. However, this term, as well as the scientific concept linked to it, is not unambiguous across all EU countries - or even within a country in some cases - usually coexisting with other terms and similar concepts. Even assuming that national conditions and ideas associated with the term social economy differ markedly and may not be comparable, it is possible to divide countries into three groups depending on their level of recognition of the social economy concept:

- Countries in which the concept of the social economy is widely accepted: In Spain, France, Portugal, Belgium, Ireland and Greece, the concept of the social economy enjoys greatest recognition by public authorities and in the academic and scientific world, as well as in the social economy sector itself. The first two countries stand out: France is the birthplace of this concept, and Spain approved the first European national law on the social economy in 2011. 
- Countries in which the concept of the social economy enjoys a moderate level of acceptance: These include Italy, Cyprus, Denmark, Finland, Luxembourg, Sweden, Latvia, Malta, Poland, the United Kingdom, Bulgaria and Iceland. In these countries the concept of the social economy coexists alongside other concepts, such as the non-profit sector, the voluntary sector and social enterprises. In the United Kingdom, the low level of awareness of the social economy contrasts with the government's policy of support for social enterprises.

- Countries where there is little or no recognition of the concept of the social economy: The concept of the social economy is little known, emerging or unknown in the following countries: Austria, the Czech Republic, Estonia, Germany, Hungary, Lithuania, the Netherlands, Slovakia, Romania, Croatia and Slovenia, a group which mainly comprises Germanic countries and those which joined the EU during the last round of enlargement. The related terms nonprofit sector, voluntary sector and non-governmental organisation enjoy a relatively greater level of recognition.

In the Netherlands, Sweden, Finland and Poland the concept of social enterprises is widely accepted. In addition to the concepts social economy, non-profit sector, social enterprise and third sector, other widely accepted notions coexist in several EU countries. In countries such as the United Kingdom, Denmark, Malta and Slovenia, the concepts voluntary sector and non-governmental organisation, more closely related to the idea of non-profit organisations, appear to enjoy wide scientific, social and political recognition. In Frenchspeaking European countries (France, the Walloon Region of Belgium and Luxembourg) the concepts solidarity economy, and social and solidarity economy are also recognised, while the idea of a Gemeinwirtschaft (general interest economy) is known in Germanic countries such as Germany and Austria. It is important to point out that in several countries certain components of the term social economy in its broadest sense are not recognised as integral parts of this sector, with emphasis instead on their specificity and separateness. This is the case of cooperatives in countries such as Germany, the United Kingdom, Latvia, and partly Portugal.

The main conclusion drawn by an investigation on the social economy in Europe is that the social economy in Europe is very important in both human and economic terms, providing paid employment to over 14.5 million people, or about $6.5 \%$ of the working population of the EU-27. These aggregates underline the fact that this is a reality which cannot and should not be ignored by society and its institutions. The second noteworthy conclusion is that, with certain exceptions, the social economy is relatively small in the new EU Member States in comparison to the 'older' 15 Member States. Therefore, if the social economy is to develop its full potential in these countries it needs to reach at least the same level as in other countries in the EU. The third conclusion is that the social economy has increased more quickly than the population as a whole in 2002-03 and 2009-10, increasing from the $6 \%$ of the total European paid workforce to the $6,5 \%$, and from 11 million jobs to 14,5 million jobs (Terziev, 2019a-k).

The social economy's growth potential in an economic and social crisis has been frequently underlined. The social economy is not only a resilient model during crises. It keeps developing and growing while other economic sectors can scarcely get by. The key data show the following:

- $10,3 \%$ of employment in France, i.e. 2,33 million employees;

- $11,8 \%$ of employment in Belgium, i.e. 367664 employees;

- 2,215,175 employees in Spain;

- $7 \%$ of employment in Luxembourg, the percentage has doubled since 2000.

- 8,3\% employment growth rate between 2009 and 2013 in Belgium;

- The Spanish social economy created 190000 jobs between 2008 and 2014 and 29000 enterprises;

- In Italy, the number of employees has increased by $39,4 \%$ over the past ten years and the social economy sector employs currently 2,2 million people.

- In France, over $67 \%$ of the employees are women;

- In Belgium, $66 \%$ of the jobs are held by women;

- In Spain, $50 \%$ of the jobs are held by women;

- Focusing on France, the social economy is established in all sectors: it is the number one employer of the social sector (62\% of jobs), sports and recreational activities (55\% of jobs) and the second employer in the financial, banking and insurance activities (30\% of jobs), $27 \%$ of jobs in arts and entertainment, $19 \%$ of jobs in education. 
- The EU market of mutual and co-operative insurance represents:

- A market share of $29,8 \%$;

- A revenue from premiums of $€ 373,5$ billion;

- Total assets amounting to $€ 2,4$ trillion;

- More than 450000 employees;

- Some 390 million insured persons/ members.

Successful social enterprises can play an important role in helping deliver on many of the Government's key policy objectives by (Terziev, 2019a-k):

- Helping to drive up productivity and competitiveness;

- Contributing to socially inclusive wealth creation;

- Enabling individuals and communities to work towards regenerating their local neighbourhoods;

- Showing new ways to deliver and reform public services;

- Helping to develop an inclusive society and active citizenship.

\section{SOCIAL ENTERPRISES IN BULGARIA}

Bulgaria, as a member of the European Union, accepts and follows EU policies in the field of social enterprise and entrepreneurship. In recent years there has been a clear European policy to promote social entrepreneurship as a key tool to tackle the challenges facing vulnerable groups or solve social issues, including replace (or displace) the traditional forms of social support (social services and payments). More and more funds from the EU budget is spent on concrete measures to support social enterprises. Bulgarian national legislation also provides comprehensive legal framework for the development of activities that have their reference to the characteristics of the social economy. But in the current legislation the terms "enterprise" and "social enterprise" is not clearly defined. Various laws give their self-definitions intended solely for the purposes of their own regulation.

The Economic and Social Council of the Republic of Bulgaria (ESC) believes that social enterprises in Bulgaria are still an untapped business model. Current social enterprises are mainly non-governmental organizations by applying the relevant legislation creating social enterprises whose business is focused on the realization of the social purpose and mission of the organization. Social enterprises in Bulgaria operate in various sectors, the most serious part are in: the delivery of social services; providing jobs for people with disabilities; mediation in finding employment of unemployed persons; provision of health services; activities in the field of education and others.

In realizing these activities the leading is not the end product but the achieved social effect on individuals themselves expressed in obtaining the necessary support to integrate into society. In this sense, there are three basic models of social enterprises:

- The most common model is the one that creates jobs and develops the workforce. By business jobs are created primarily for people with disabilities. Most often the social enterprise is the employer of people with disabilities in order to achieve the integration of persons with disabilities in the labor market and create conditions for a better life.

- Another popular model of a social enterprise is the one in which the enterprise produces goods and seeks markets, also engaging with their distribution. Most often social enterprises involve persons with disabilities in the form of occupational therapy involved in the production of certain goods. Existing social enterprises in Bulgaria within this model are engaged in the manufacture of certain products by persons who are unemployed or socially excluded. The aim is to enable them to work and improve their social inclusion.

- The third existing model in Bulgaria is related to the provision of social services generally through payment of external customers, while social enterprise provides social services to its members. Payment is under contract with the state or a municipality. Within this model, services are provided to different users paid directly to the social enterprise for the direct service.

In Bulgaria there is a freedom in relation to self-determination as a social enterprise and choice of form by which to function. At the time, regardless of the National concept of social economy and its implementation plan, a systematic state policy is lacking, providing easily accessible and flexible incentives for their development, including all forms. Rather, private donors and programs develop initiatives aimed at 
increasing the capacity and the incentives. Entirely by the organizations themselves it depends on whether and how to define as a social enterprise that comes to the question whether this means real and whether it is long-solving specific social problems and seeking support for them.

Currently Bulgarian legislation provides a good basis for economic and social activities with social impact. Over 30 preferential regime, including tax and related deductions that apply in the corporate economy are directly applicable to undertakings and social economy organizations. A more precise analysis of this system of preferences warrants to offer additional incentives and to introduce profiling of such measures to the specifics of the social economy. The creation of the routine functioning mechanism for monitoring public activities with social impact, collecting and analyzing data on their condition, activity and results, as well as their needs for improving the legislative framework to maintain and stimulate their activity is an immediate task inherent in the state administration, which when established necessary, in consultation with all stakeholders, will take the amendments to the regulations on businesses and social economy organizations:

- For legal recognition;

- For statistical recognition;

- Profiling, respectively expanding the scope of the preferential arrangements for full inclusion in their subjects of the social economy.

Legal and statistical recognition of enterprises and social economy organizations is an important prerequisite for a clear and fair interaction between the state and the social economy. In particular, statistics on these activities will support the state for accurate orientation and development not only of policies for the social economy, but also the general policies of social protection (Terziev, 2018-d; Terziev, Georgiev, 2018e-f; Terziev, Arabska, 2014; Terziev, 2015-b; Terziev, Arabska, 2016a).

\section{CONCLUSION}

The social enterprise is currently not widely understood as a concept; it is also perceived by many to be ill defined. Better support for the sector will come when government (at all levels), the financial community and business advisors understand its nature and needs better, are convinced of its value, and alter their practices to incorporate the social enterprise model. To achieve these results, we need to be able to demonstrate the current and potential contribution of the sector to the economy and to the delivery of social objectives. We need to engage in active promotion, to give a higher profile to the sector and help spread understanding. Raising awareness and celebrating success and entrepreneurial achievement is important. The sector also needs to come together to make social enterprise stronger and more visible. Work to enable social enterprises to measure their social, environmental and economic impact, to benchmark themselves against other businesses, and to reach appropriate quality standards, will also help to establish the value of social enterprise.

The contribution of the social enterprises to the socio-economic development of a country can be seen from different perspectives:

They provide access to basic services (social, educational and health) of local communities, including the most vulnerable population groups;

They contribute to a more balanced use of local resources, and with the support of the inter-ested parties, which promotes inclusive governance models thus enabling local communities in making strategic decisions;

They support the opening of new positions as a result of new services provided to disadvantaged people;

They include in the labor market minority groups, single women, people with disabilities and others, who are excluded from the opportunities to generate income.

In practice, there are major differences in the way in which social enterprises are treated in different countries. However, one of the most visible effects of institutionalization of the social enterprises in various EU countries is that this process encourages this type of entrepreneurship to position itself and seek stability in the conditions of a market economy.

In fact, the financial viability of social enterprises depends on the efforts of their members to provide adequate resources to the enterprise. Regardless of what type of resources they use, we can say that, as a general trend, the European Union shows continued interest and invests in the development and improvement of social entrepreneurship to meet the current social needs of the member states. It was proved when the Structural Funds were reformed in order to create more effective tools to support balanced regional and social development. Numerous activities affecting social capital are funded through them. These activities cover areas such as social dialogue, labor mobility, vocational education, information society 
IJASOS- International E-Journal of Advances in Social Sciences, Vol. V, Issue 14, August 2019

and new sources of employment (Terziev, Arabska, 2014; Terziev, 2015-b; Terziev, Arabska, 2016a).

\section{REFERENCE LIST}

Georgiev, Marin. (2016). Obshtestvenoto i ikonomichesko razvitie v konteksta na sotsialnite politiki. // Spisanie za nauka "Novo znanie“. Visshe Uchilishte po Agrobiznes i Razvitie na Regionite, 5, 2016, N 4, str. 26-41, ISSN 2367-4598 (Online), (Print) ISSN 1314-5703 (Георгиев, Марин. Общественото и икономическо развитие в контекста на социалните политики. // Списание за наука „Ново знание“. Висше училище по агробизнес и развитие на регионите, 5, 2016, N 4, стр. 26-41, ISSN 2367-4598 (Online), (Print) ISSN 1314-5703.

Georgiev, Marin. (2017). Sbalansirovannaya karta kak alyternativa malogo biznesa. // Innovatsionnie tehnologii v nauke novogo vrmeni, Sbornik statey Mezhdunarodnoy nauchno - prakticheskoy konferentsii 1 fevralya 2017 g., Ufa NITS AETERNA, Chasty 1, 2017, s. 43-49, ISBN 978-5-00109004-5, ISBN 978-5-00109-007-6 (Георгиев, Марин. Сбалансированная карта как альтернатива малого бизнеса. // Инновационніе технологии в науке нового врмени, Сборник статей Международной научно - практической конференции 1 февраля 2017 г., Уфа НИЦ АЭТЕРНА, Часть 1, 2017, с. 43-49, ISBN 978-5-00109-004-5, ISBN 978-5-00109-007-6).

Georgiev, Marin. (2017a). Impacts of active social programs on labor market. // Mezhdunarodnayy nauchnayy zhurnal „Innovatsionnaya nauka“. NITS Aeterna, N 02-1, 2017, pp. 139-143, ISSN 24106070 (Georgiev, Marin. Impacts of active social programs on labor market. // Международный научный журнал „Инновационная наука“. НИЦ Аэтерна, N 02-1, 2017, pp. 139-143, ISSN 24106070).

Terziev, V., Kanev, D. (2019). Modern developments in behavioral economics. // Smart Technologies and Innovations in Design for Control of Technological Processes and Objects: Economy and Production Proceeding of the International Science and Technology Conference „FarEastCon-2018” Volume 138, October 2-4, 2018, Vladivostok, Russian Federation, pp. 10-23, 2019, (Print) ISBN978-3-030-15576-6, (Online) ISBN978-3-030-15577-3.

Terziev, Venelin. (2019a). Provision of integrated employment and social assistance services in Bulgaria. // Smart Technologies and Innovations in Design for Control of Technological Processes and Objects: Economy and Production Proceeding of the International Science and Technology Conference „FarEastCon-2018” Volume 138, October 2-4, 2018, Vladivostok, Russian Federation, pp. 24-39, 2019, (Print) ISBN978-3-030-15576-6, (Online) ISBN978-3-030-15577-3.

Terziev, Venelin. (2019b). Problems of control in the social sphere. // INTCESS 2019- $6^{\text {th }}$ International Conference on Education and Social Sciences, 4-6 February, 2019, Dubai, International Organization Center of Academic Research, Istanbul, Turkey, pp. 577-593, ISBN: 978-605-82433-5-4.

Terziev, Venelin. (2019c). The criterion "competence" in the economic sector. // INTCESS 2019- $6^{\text {th }}$ International Conference on Education and Social Sciences, 4-6 February, 2019, Dubai, International Organization Center of Academic Research, Istanbul, Turkey, pp. 1241-1247, ISBN: 978-605-824335-4.

Terziev, Venelin. (2019d). Social policy and labor market development in Bulgarian transition period. // INTCESS 2019- $6^{\text {th }}$ International Conference on Education and Social Sciences, 4-6 February, 2019, Dubai, International Organization Center of Academic Research, Istanbul, Turkey, pp. 703-714, ISBN: 978-605-82433-5-4.

Terziev, Venelin. (2019e). Theoretical basis of development of labor market and social policy in the republic of Bulgaria. // INTCESS 2019- ${ }^{\text {th }}$ International Conference on Education and Social Sciences, 4-6 February, 2019, Dubai, International Organization Center of Academic Research, Istanbul, Turkey, pp. 715-726, ISBN: 978-605-82433-5-4.

Terziev, Venelin. (2019f). The problem of social efficiency- Indicators for social efficiency. // INTCESS 2019$6^{\text {th }}$ International Conference on Education and Social Sciences, 4-6 February, 2019, Dubai, International Organization Center of Academic Research, Istanbul, Turkey, pp. 669-678, ISBN: 978605-82433-5-4.

Terziev, Venelin. (2019g). Experiencing social policy development and efficiency measurment. // INTCESS 2019- $6^{\text {th }}$ International Conference on Education and Social Sciences, 4-6 February, 2019, Dubai, 
International Organization Center of Academic Research, Istanbul, Turkey, pp. 679-686, ISBN: 978605-82433-5-4.

Terziev, Venelin. (2019h). Efficiency and assessment of social technology. // INTCESS 2019- $6^{\text {th }}$ International Conference on Education and Social Sciences, 4-6 February, 2019, Dubai, International Organization Center of Academic Research, Istanbul, Turkey, pp. 687-694, ISBN: 978-605-82433-5-4.

Terziev, Venelin. (2019i). Conceptual framework of social adaptation. // INTCESS 2019- $6^{\text {th }}$ International Conference on Education and Social Sciences, 4-6 February, 2019, Dubai, International Organization Center of Academic Research, Istanbul, Turkey, pp. 494-503, ISBN: 978-605-82433-5-4.

Terziev, Venelin. (2019j). The dependence social adaptation- socialization. // INTCESS 2019- th $^{\text {th }}$ International Conference on Education and Social Sciences, 4-6 February, 2019, Dubai, International Organization Center of Academic Research, Istanbul, Turkey, pp. 478-485, ISBN: 978-605-82433-5-4.

Terziev, Venelin. (2019k). Social activity and human resources as social development factors. // INTCESS 2019- $6^{\text {th }}$ International Conference on Education and Social Sciences, 4-6 February, 2019, Dubai, International Organization Center of Academic Research, Istanbul, Turkey, pp. 546-553, ISBN: 978605-82433-5-4.

Terziev, Venelin. (2018). The active model of a social programme and its strategic advantage. // ADVED 2018- $4^{\text {th }}$ International Conference on Advances in Education and Social Sciences Abstracts \& Proceedings, 15-17 October 2018- Istanbul, Turkey, International Organization Center of Academic Research, www.ocerints.org, Istanbul, Turkey, 2018, pp. 189-203, ISBN: 978-605-82433-4-7.

Terziev, Venelin. (2018a). Active social programs development in Bulgaria: contemporary challenges and social management instruments. // ADVED 2018- $4^{\text {th }}$ International Conference on Advances in Education and Social Sciences Abstracts \& Proceedings, 15-17 October 2018- Istanbul, Turkey, International Organization Center of Academic Research, www.ocerints.org, Istanbul, Turkey, 2018, pp. 149-163, ISBN: 978-605-82433-4-7.

Terziev, Venelin. (2018b). Social assistance services and integrated employment in Bulgaria. // ADVED 2018- $4^{\text {th }}$ International Conference on Advances in Education and Social Sciences Abstracts \& Proceedings, 15-17 October 2018- Istanbul, Turkey, International Organization Center of Academic Research, www.ocerints.org, Istanbul, Turkey, 2018, pp. 164-177, ISBN: 978-605-82433-4-7.

Terziev, Venelin. (2018c). Impact of the labor market policies for ensuring employment. // ADVED 2018- $4^{\text {th }}$ International Conference on Advances in Education and Social Sciences Abstracts \& Proceedings, 1517 October 2018- Istanbul, Turkey, International Organization Center of Academic Research, www.ocerints.org, Istanbul, Turkey, 2018, pp. 178-188, ISBN: 978-605-82433-4-7.

Terziev, Venelin. (2018d). Importance of human resources to social development. // ADVED 2018- $4^{\text {th }}$ International Conference on Advances in Education and Social Sciences Abstracts \& Proceedings, 1517 October 2018- Istanbul, Turkey, International Organization Center of Academic Research, www.ocerints.org, Istanbul, Turkey, 2018, pp. 204-212, ISBN: 978-605-82433-4-7.

Terziev, V., Georgiev, M. (2018e). A strategic framework for the development of social entrepreneurship in Bulgaria. // Knowledge - International Journal, August 2018, Institute of Knowledge Management, Skopje, Macedonia, 25, 2018, N 1, pp. 23-34, ISSN 1857-923X (for e-version), ISSN 2545 - 4439 (for printed version).

Terziev, V., Georgiev, M. (2018f). Support for the development of social entrepreneurship in Bulgaria. // Knowledge - International Journal, September, 2018, Institute of Knowledge Management, Skopje, Macedonia, 26, 2018, N1, pp.57-74, ISSN 1857-923X (for e-version), ISSN 2545 - 4439 (for printed version).

Terziev, V., E., Arabska. (2014). Assessment of active social policies' impacts on labor market in the Republic of Bulgaria. Kolektivnaya monografiya "Sotsialyno-ekonomicheskie i pravovay razvitiya ekonomiki“, Ufa, Aeterna. Rossiya, 2014. ISBN 978-5-906769-97-8, str. 3-57 (Terziev, V., E. Arabska. (2014). Assessment of active social policies' impacts on labor market in the Republic of Bulgaria. Колективная монография „Социально-экономические и правовы развития экономики“, Уфа, Аэтерна. Россия, 2014. ISBN 978-5-906769-97-8, стр. 3-57).

Terziev, Venelin. (2015). Impact of active social policies and programs in the period of active economic transformations in Bulgaria, „East West” Association for Advanced Studies and Higher Education, Vienna, 2015, ISBN 78-3-903063-44-0, 434 p. 
Terziev, Venelin. (2015a). Assessment of active social policies impact of social policies on transformation processes in bulgarian economy, Moscow, 2015, Publisher „Перо“, 110 p.

Terziev, Venelin. (2015b). Opportunities for improving the efficiency of the social adaptation of servicemen discharged from military service in Bulgaria:- Novosibirsk: Publisher CRNS, 2015. ISBN 978-5-00068402-3, $270 \mathrm{p}$.

Terziev, V., E., Arabska. (2016a). Effektivnoe vliyanie na raynok truda posredstvom uluchsheniya realizatsii sotsialynoy politiki. Novosibirsk: Izdatelystvo TSRNS, 2016. ISBN 978-5-00068-496-2, $312 \mathrm{str}$ (Терзиев, В., Е. Арабска. (2016а). Эфрфективное влияние на рынок труда посредством улучшения реализации социальной политики. Новосибирск: Издательство ЦРНС, 2016. ISBN 978-5-00068-496-2, 312 стр). 